This item was submitted to Loughborough's Research Repository by the author.

Items in Figshare are protected by copyright, with all rights reserved, unless otherwise indicated.

\title{
Women, feminism, and art schools: the UK experience
}

PLEASE CITE THE PUBLISHED VERSION

https://www.forarthistory.org.uk/our-work/the-annual-conference/

\section{VERSION}

AM (Accepted Manuscript)

\section{PUBLISHER STATEMENT}

This work is made available according to the conditions of the Creative Commons Attribution-NonCommercialNoDerivatives 4.0 International (CC BY-NC-ND 4.0) licence. Full details of this licence are available at: https://creativecommons.org/licenses/by-nc-nd/4.0/

\section{LICENCE}

CC BY-NC-ND 4.0

\section{REPOSITORY RECORD}

Robinson, Hilary. 2019. "Women, Feminism, and Art Schools: The UK Experience". figshare. https://hdl.handle.net/2134/32005. 


\section{Hilary Robinson}

April 2017

AAH conference

Women, feminism, and art schools: the UK experience

The relationship between women, feminism, and art schools is complex and geographically specific. While the development of the 1970s American women's art movement is often connected with particular programmes (i.e., the Feminist Art Program [Fresno State College 1970-1993; CalArts 1971-1975) and the establishment of alternative fee-paying institutions (i.e. Feminist Studio Workshop [LA, 1973-1981]; New York Feminist Art Institute [1979-1990]) the UK experience was very different. Here, women tended to organize in autodidactic groups outside of art schools, and with the later exception of Griselda Pollock's MAFEM at Leeds (1993-2003), the influence of feminism in studio art education in art schools was restricted to ad-hoc electives, seminars or the influence of individual teachers. Yet the numbers and percentages of women art students has increased exponentially from the 1970s to the present day.

Grounding the discussion in the specific history of the UK experience, and drawing upon my former experience as a Dean, this paper will move to explore the situation for women in art schools in the UK today. At a time when Universities have been moved with eye-watering speed to system based upon fees, loans, student debt, precarious labour, and governmental modeling of students as customers, what are the economic and career prospects for this generation of women artists? Five decades after the first pedagogies informed by the Women's Liberation Movement, what are the pedagogies used to educate predominantly female cohorts? What might feminist strategies be?

1. Stats

Stats of male/female students

Stats of male/female staff

2 What are we educating them for?

Fawcett stats

Griselda saying that women were used to fill the schools - 1984

Precariat

3 feminist pedagogies

Precarious workers Brigade - Sylvia Federici - consciousness raising.

Judy Chicago - CR techniques?

My shift at UU in crits

4 What does it take to teach as a feminist, to teach feminist, rather than teach feminism?

In the UK at present, both Higher Education and the arts in general are in a state of crisis. Higher education has within two decades moved from a position where tacitly or explicitly governments held that it was a common good for the country, to which we all would contribute through taxes, to being now regarded as something that is of benefit primarily to the individual 
and their future careers, and which therefore should be paid for by the individual, their families, their indebtedness, and their future earnings.

The arts too, long supported by the state through the arts councils, have gone through round after round of de-funding. Founded in the immediate post-war financial crisis and expanded in the 1960s at a time of budget cuts, the arts council ethos was (and still is) one of aligning excellence and greater engagement.

For all creative arts and design (a broad category that includes the performing arts) the student numbers nationally show about $2 / 3$ the numbers of male to female students. For women, since $2007 / 08$, the figures started with a low of 98,620 and a high of 112,570 , and were at 108,560 last year.

For the male students, the figures have been more steady with a low of 61,030 , and a high of 69,510 . The two lowest years were the last two.

What we are seeing is an increasing number of women and a decreasing number of men.

Where these students are as the undertake their studies is also instructive.

Last year, $63.5 \%$ of undergrad arts and design students were women;

$65.9 \%$ of taught $\mathrm{p} / \mathrm{g}$ students were women

$53.2 \%$ of research $\mathrm{p} / \mathrm{g}$ students were women.

So what we see is that a slightly disproportionately high number of women follow the socalled professional practice route of the masters programme; and a distinctly disproportionately high percentage of men take the research degree route - the highest level of educational qualification available, and arguably the most intellectually challenging, where the student has to be most personally resourceful, and your tutors are not teaching you but supervising your way through your project.

The figures that I could get with a focus on the visual arts were for the years 2007/08 to 2011/12. What we see here is that in Fine Art, the numbers of women is fairly steady - 13,33013,705. Well under half the students are male, with a slow decline from 5,985 down to 5,370.

The male design students remained steady at between 22,115 to 23,290 , but the women design students rapidly increased from 37,590 to 45,725 .

Film and photo students, both men and women, increased, but the split is more even.

And finally, crafts, where the numbers are small, have about 4 times as many women as men students.

What about the stats for employment in art schools?

49.4\% of A\&D staff are women (NI: 37.9\%; Wales: 41.7\%; Scotland: 49.3\%; England: $49.9 \%)$

$48.2 \%$ of A\&D staff with permanent contracts

$52.6 \%$ of A\&D staff with fixed term contracts (this does not include visiting or hourlypaid staff which is where the ).

$50.9 \%$ of $A \& D$ teaching-only contracts

$48.2 \%$ of A\&D research-only contracts 
$41.5 \%$ of A\&D full-time staff

$54.7 \%$ of A\&D part-time staff

$50 \%$ of A\&D non-professor level staff

$34.9 \%$ A\&D of professors

These statistics are significant for two reasons. First is that the majority of students are women, but they are not seeing that proportion reflected in the contracted academic staff; nor are they seeing it in the seniority of the staff teaching them.

But there are also big implications for the financial security of the women doing the teaching: they are disproportionately in the less prestigious ranks and contract-types.

But what of the exhibiting of work, the most palpable way in which someone demonstrates that they are an artist?

East London Fawcett audited London galleries from April 2012-April 2013

In the commercial art world, of 134 commercial galleries in London, which collectively represent 3163 artists:

$-31 \%$ of the represented artists are women,

$-78 \%$ of the galleries represent more men than women,

$-17 \%$ of the galleries represent more women than men,

$-5 \%$ represent an equal number of male and female artists,

- 22 galleries $(16 \%)$ had male representation of $80 \%$ or more, whilst only 3 galleries $(2 \%)$ had female representation of $80 \%$ or more,

-30 of the galleries $(22 \%)$ represent an equal number, or more female artists than male.

Analysis of the 100 highest grossing auction performances of 2012 revealed there were no women on the list.

Over the same period, ELF audited the 133 solo shows which featured in the exhibition programmes of 29 non-commercial galleries in London:

$-31 \%$ of these shows were by female artists, (Which is the same proportion as are represented in the commercial galleries)

- Nearly a third of the galleries (31\%) included no female solo shows (but a number of male solo shows),

- Over two thirds of the galleries exhibited more than $60 \%$ male solo shows,

- Only 1 of the 29 galleries exhibited an equal number of male and female solo shows,

- Only one of the gallery programmes that ELF audited (3\%) featured all female solo shows, whereas $31 \%$ of the gallery programmes featured all male solo shows.

At Frieze Art Fair 2012, 3441 artists were exhibited from 135 international galleries. $-27.5 \%$ of the artists represented at Frieze Art Fair 2012 are women (excluding collaborations) (3.5\% less than are represented in the London galleries).

$-1.5 \%$ of the galleries represent less than one third male artists,

- $67 \%$ of the galleries represent less than one third female artists

$-3.7 \%$ of the galleries at Frieze 2012 represent the same number of male and female artists 
So, if in Fine Art programmes over $2 / 3$ of the students are women, and if just half those starting to work in art schools are women, and if only $1 / 3$ of the highest ranking art school teachers are women, and if added to this, between a quarter and a third of the artists who are shown in galleries are women, then I think we have some serious questions about how art school curricula are structured, and about who is educating who, and how and why.

Tied into such questioning of course are fundamental questions of the governance of art schools in the UK today. The vast majority of them are incorporated into Universities - mainly the post-92's, the old polytechnics, which were established with similar governing structures to corporations, with Vice Chancellors having the functions and powers of CEOs (this is distinct from the older universities which contain just a handful of Fine Art programmes, like Leeds, Edinburgh, Reading, and the Slade). Art Schools that have remained outside larger universities the stand-alone, or specialist institutions - have however, also generally embraced university status whether in groups like University of the Arts London, or alone like Falmouth, or Glasgow. What this means is that just about all art schools in the UK are subject to the structures and requirements of successive governmental policies, from the National Student Survey, to the Research Excellence Framework, to the Destination of Higher Education Leavers survey, to the Teaching Excellence Framework, to the QA, and many other acronyms; and of course also informed by the government's approach to funding of institutions, and the rapid shift in ideology from Higher Education being a good for the Country, paid for by the state through everyone's taxes, to Higher Education being good for the individual, paid for by by student fees and therefore, for all but a few, ongoing student debt.

You may detect in my tone the weary note of a recovering Dean. Nine years in that position in the UK and the USA, and prior to that, three years as a Head of Department and three as a research director, has certainly meant that I have had to be up close and personal with the changes that have been happening. But I also speak as a feminist, and as the first person in my family to go on to higher education, as someone with class consciousness of education policy and practice, and also the legacy of a diverse racial and national heritage over three generations.

So, while reference to such matters as student debt or the NSS may appear to be technical, it does have a bearing. From where I stand with a feminist political analysis, the gender politics of art education in Higher Education run so deep that they are almost invisible. They are the water that we fish swim in, with our short term memories (any cohort of students simply does not have the knowledge and experience of the cohort that just graduated; and any reference to the past on the part of staff runs the danger of facing incomprehension, being presented as romanticised nostalgia, or appearing as a wish for inertia.

As Gayatri Spivak insists, every analysis must be gendered to expose its full politics and structures; and as Noam Chomsky has pointed out, debt and precarious employment lead to compliance.

3. feminist pedagogies

Judy Chicago - CR techniques? 
My shift at UU in crits

Kyla Wazana Tompkins

Helena's Feminist duration reading group

To go back to the figures that I showed earlier: we are clearly in a situation where women are being disadvantaged by the structures in which they are being educated and in which we (as educators) are hoping they will have their careers.

What is to be done about this? CalArts

Legacy of feminist education: Judy Chicago and the feminist art program - Fresno then

Simultaneously at CalArts Sheila De Bretville and the women's design program

The programmes that Linda Nochlin ran in art history at Vassar

All these were within the university structures

This is not the history of the development of the women's movement in art in the UK, which happened mostly outside the art schools and the universities. The Women's Art History Collective; the Women's Workshop of the Artists Union, and other such ventures - generally happened independently.

Art school education in the " 60 s and '70s in the UK was quite distinct from that in the USA. Rather than the American liberal arts model, where students are required to take a number of courses from different disciplines, leading to a concentration in one (the 'major'), students in the UK apply to study art, and would spend most of their time in the studios with a lot of selfdirected activity, interspersed with art history and time-specific classes, such as life-drawing or other specialisms. The UK aim generally is to produce graduating students who would be graded on an exhibition of work and a written thesis, and who demonstrated a clear 'voice' as artists: some of Britain's best known artists, including Damien Hirst, Jenny Saville, and Willie Doherty, became widely known for work presented at the undergraduate level, and did not take graduatelevel courses. Some courses required the students to take a small number of related elective units; when some colleges and universities started changing to modular systems in the 1980s and 1990s, the opportunity for this was increased. Ironically, therefore, the Feminist Art Program at CalArts was attempting to replicate the day-in, day-out, studio focus found in the UK system, but in a woman-only, feminist format; while the structure in the UK made it more difficult for explicitly feminist input to be provided on a systematic basis until the modular system was introduced. Also ironic is that in the US system, individual professors have total responsibility for assigning grades for their courses; but in the UK, a rigorous system of peer-group external examining means that all grades are subject to inspection and challenge, in the name of achieving parity throughout the system - an upper $2^{\text {nd }}$ class degree (for example) in one institution should mean the same level of achievement as in another. So while the US system is potentially open to individual bias - grade inflation, or personal likes or prejudices - the UK system should be far more transparent. However, as the UK system was historically populated and run to a huge extent by men, and still is disproportionately so, as we have seen, women students can find 
themselves battling not just individual prejudice, but the weight of a patriarchal structure and assumptions about women as artists. The introduction of more radical approaches and a more rigorous intellectual curriculum, usually through conceptual studio work or the study of contemporary critical theory, helped foster some feminist approaches in some schools, but this was a precarious challenge to the system dependent upon determined groups of lecturers.

There are clearly shifts that individual tutors or groups of students can make to ensure that teaching practices are more inclusive.

1. For example, when students on an elective module I was teaching of feminism and art at the University of Ulster asked for the module to be expanded into the studios, rather than follow the usual crit structure of the artist presenting followed by the group responding, I used the practice from consciousness-raising of everyone getting 3 minutes to talk - or to sit in silence if they wished not to. Sometime we would go round twice. Only then would the artist speak. This took us to quite different places than crits usually would. Other staff noticed this, and began adopting similar approaches in their own student groups, particularly on the MFA.

2. There are possibilities for making more subversive moves. At a workshop on radical pedagogies at the ICA about three years ago, the break-out group I was in included three apparently white men who all taught at the same London art school. Immediately they began to lament the possibility of making any radical changes, as their teaching was tied to required learning outcomes and criteria against which the students would be graded. The challenge given them was to consider mot mentioning any male artists for a term; or not mentioning any white artists, but only artists of colour, or only artists from outside western europe and the USA. They looked, to a man, horrified.

3. We can probably learn a lot from the attempts to re-write art school curricula in South Africa. There, clearly, an art history has been taught that has a total disconnect with the lives and culture of a majority of the people of the country. What colleagues are attempting there is not to deny the impact of european culture, but to develop frames of reference that comprehend and critique African cultures and histories, and the impact and legacy of European culture and white rule.

4. There are things can do about how we teach. For example: Kyla Wazana Tompkins published an article in the LA review of books last year, on how she teaches community college students to read feminist and queer critical theory and pose questions. It is an exemplary text on how to engage students (who may feel excluded for all level of reasons) with ideas and critique. Particularly powerful in her text - and of particular interest in teaching art - is how she deals with the personal, and with feelings and affect. The personal is the political, but unless we step back from the personal and analyse it, we will never reach the political. How she asks her students to explore the writers they study would be a fascinating model to use regarding the artists that students bring to us as important to them, or that we present to them as significant.

5. There are also things we can do for ourselves. I would like to thank Helena Reckitt for alerting me to Tompkins' text, through her Feminist Duration reading group; and also for her membership along with about 8 others of Write-Read-Write, a feminist art writing group that I set up a couple of years ago. Such initiatives are sustaining intellectual and emotionally in the 
face of the requirements of full-time academia, or the precocity of hourly-paid teaching, when you may be wary - or weary - of your institutional colleagues. I think that all of us in these two groups have found insights and practices that we can re-introduce into the spaces and places of education..

6. Think about positions of power. My experience as Dean at Middlesex and as Dean at Carnegie Mellon in the USA was that when we advertised for Heads of Department, a Deputy Dean, Directors of programmes and so forth, very few women applied. They did apply for professorships, which was wonderful, but not so much for those roles where interventions could be made at a more structural and strategic level, - often the sort of move that would have a real impact upon the working situation of a junior colleague - and where an ethos could be encouraged to try to ensure that the bureaucracy works for the students and for the art, rather than the other way round. Yet these roles are often where the analytical approach encouraged by one's politics can be deployed and put to good use.

\section{Employability agenda}

\section{Precarious workers Brigade - Sylvia Federici - consciousness raising.}

One of the things that is particularly notable about much of the activism of the last few years is how much of it is led by women. Not only groups like Femen in Ukraine and France, La Barbe in France, or Sisters Uncut in London, but also crucially \#blacklivesmatter, which was established by queer black women. Much of recent activist practice has also been informed by artists and by visual culture more broadly; and the Victoria and Albert Museum (to give just one example) has responded with exhibitions like Disobedient Objects and by adding objects like a pussy hat to its collection. If we look back to the 19-year Greenham Common protest, this should not be surprising, but it does bear pointing out.

In the UK, the Precarious Workers Brigade who describe themselves as 'UK-based group of precarious workers in culture \& education' have been working for the last 7 or so years on issues of unpaid internships, volunteer labour in cultural institutions, and the practices of some arts schools to encourage their students to take such opportunities, despite their own financial precarity and debt vulnerability. Their recent publication 'Training for Exploitation? Politicising Employability and Reclaiming education' is another paper I would recommend to people. It can be downloaded for free.

In it they advocate for a shift in the discourses around education, away from the employability agenda, and towards thinking about vocation. Employability, one of the measures by which programmes and universities are ranked, is of course a requirement for students who need to repay their loans and debts. Vocation, on the other hand, is about one's calling, one's role in society and in communities, and how one contributes. 
Interestingly, the forward is written by Sylvia Federici. Federici was a key feminist theorist of the 1970s who was one of the first to analyse the economics of housework, and the unpaid contribution made mainly by women to the maintenance of workers and children through material and affective caring. She mentions the tools that are outlined in the book to challenge the present conversations, and says that 'as a feminist I recognise many of these tools from past and contemporary practices of consciousness raising. They are effective, and I encourage readers to use them.'

The lessons of Federici are useful to bear in mind when it comes to thinking of the alternative art school scenarios that have been set up in recent years, from Open School East to initiatives like Ryan Gander's development of a private school. Matching her analysis with the direct questions of Gustave Metzler, who in 1970 challenged artists:

Do you eat?

Where does the money come from?

- $\quad$ Private funds

- $\quad$ State funds

- Sale of work

- $\quad$ Through being employed

Does it matter where your money comes from?

Free art education is an ideal: but presently such initiatives are being paid through a mixture of three sources:

1 The arts Council;

2 private philanthropy

3 donated, volunteer labour.

And in each case, these can be subject to feminist questioning - as indeed could the structures of unregulated education: are they more free of sexism and racism and discriminatory structures than present art schools? What forms of redress do students have if things go wrong, if there is harassment or individual discrimination?

\section{Conclusion.}

I hope it has become clear by now that I am not advocating for any 